\title{
Professional training for self-employment of future specialists of the agro-industrial complex
}

\author{
Oleg Sirotkin ${ }^{1}$, Svetlana Belovitskaya ${ }^{1, *}$, Mohamed Kadom Mahdi Al Hussini ${ }^{2}$ \\ ${ }^{1}$ Don State Technical University, 1, Gagarin sq., 344003, Rostov on Don, Russia \\ ${ }^{2}$ Baghdad university, College of Physical education, Baghdad, Iraq
}

\begin{abstract}
The article is devoted to the problem of professional training of specialists of the agro-industrial complex for self-employment as a factor of competitive ability of personnel. The authors note the relevance of this problem both in theoretical terms and at the practical level. Based on the content analysis of the content of the regulatory database, it is shown that in the period from 2013 in the Russian Federation, farms and individual entrepreneurs in the fields of agro-industrial complex represent an upward trend. The article deals with the relationship between professional training of specialists and existing strategic problems of development of the Russian agro-industrial complex. The necessity of training specialists of the agro-industrial complex, contributing to openness, concretization, integration, differentiation, as well as targeting in professional activities, is justified. A set of professional training measures for self-employment of specialists in the agro-industrial complex can become one of the reasons for the growth of the country's agricultural industry.
\end{abstract}

\section{Introduction}

Effective training of specialists in the agro-industrial complex is one of the most important factors in improving competitiveness in the labor market in the Russian Federation. Professional training of specialists in the agro-industrial complex can be considered as pedagogical aspects that affect the disclosure and development of the "internal reserves" of the individual. Therefore, the organization of the educational process is the building of the trajectory of research self-development of specialists in the agricultural sector through education and self-education. Thus, the personnel policy determines the General line, the basic settings in the strategy of professional training and develops a systematic approach to the development of professionalism of specialists of the agro-industrial complex. The Russian agro-industrial market has been recognized as one of the fastest growing markets in the world over the past decade. Today, the appearance and structure of the domestic agricultural industry have changed. Most large and medium-sized specialized enterprises have modernized and expanded their production bases, acquiring equipment that meets the modern world level.

Also changes in the structure of the agricultural production process are considered. These changes are associated with the emergence of small organizations with new forms of

* Corresponding author: belovickaja-svetlana@rambler.ru 
ownership, instead of large collective enterprises that were under state control. In connection with the dynamic changes in the labor market, new requirements are also being presented for the professional training of future specialists in the agricultural sector.

Taking into account the analysis of the labor market's need in the specialists of the agro-industrial complex, solving the issues of professional training of future specialists in the agro-industrial complex on a new, higher level requires to ensure the acquisition of professional knowledge and skills. On the other hand, it requires to train specialists who are competitive in sustainable socio-economic development of the modern agricultural sector. An important aspect is the concept formulation of specialists in agricultural sector training, in accordance with the improvement of the mechanisms of professionalization of personnel.

We consider the improvement of the mechanisms of professionalization of personnel a connection between the career and social self-realization of future specialists in the agricultural sector and the modernization of professional skills.

Thus, we can agree that the professionalization of the agro-industrial complex implies the acquisition a profession that is respected in society and demanded by future specialists in the agricultural industry. However, in the course of the study, we hypothetically suggested that the above requirements are insufficient, since in accordance with the profession in the agricultural sector at the current level, employment may not be worthy of professional and material reward. In this regard, we consider the effectiveness of professional training of future specialists in the agricultural sector, in accordance with professional and official forms of development.

Today, an essential characteristic of the Russian agro-industrial complex is the uneven distribution of production capacity across the country. In the Strategy of sustainable development of rural territories of the Russian Federation for the period till 2030, approved by decree of the Government of the Russian Federation from February 2, 2015 No. 151-p (as amended by Executive order of the Government of the Russian Federation from 13.01.2017 N 8-R), is considered a differentiated approach to rural development. The presence in Russia of 4 types of subjects of the Russian Federation with different types of development and agricultural use, the potential and limitations of rural development [11], indicates that the share of agro-industrial producers in our country is quite large. Russian agro-industrial producers compete with Western ones, expanding their presence on the market not only by acquiring large and small regional enterprises, including in related industries, but also by training and improving the professionalism of specialists.

Because of this, we see it necessary to understand the professional training of future specialists in the agricultural sector as a set of pedagogical measures aimed at developing personal and professional characteristics of personnel. These measures will form for future specialists psychological skills to perform new functions and solve new social problems.

Currently, the agricultural industry of the Russian Federation is highly profitable and dynamically developing. Western companies prefer to invest in promoting their own brands. Russian Russians actively study customers ' tastes and start producing products that are made according to Russian recipes with Russian names. Every year, the interest of large international companies in the domestic agricultural market increases, and the likelihood of new producers increases, which leads to increased competition in the industry.

Summarizing the above, we note that the comprehensive diversification of the Russian agro-industrial economy consists both in supporting farms and in creating conditions for self-employment of agro-industrial specialists. By examining this aspect, it becomes obvious that we need to understand the pedagogical approach to the professional training of specialists in the agro-industrial complex, which can include two target areas in the educational process (figure 1).

The development and implementation of the training workshop "Self-employment of a specialist in the agricultural sector" during the training of future specialists is considered by 
us as one of the leading areas of the educational environment, which can subsequently ensure the economic security of the agricultural sector as a whole. It is important to note that the agricultural industry has a number of features that require special regulation. In this regard, the implementation of the training workshop will solve the following problems:

- the willingness of a certified specialist to study the internal characteristics of the agricultural industry in a country, region, municipality;

- the professional ability of a specialist to investigate the development factors of agricultural sectors;

- the desire of a specialist to logically analyze the demand for agricultural products and outline the prospects for the development of a separate branch of the agricultural sector.

We consider the second direction in the form of scientific and consulting support for the sustainable development of individual entrepreneurship. It is aimed at preparing future agricultural specialists to work with the information resources of this industry. We consider the issue of professional training of young specialists to be able to analytically evaluate the means of informational monitoring of the development of the agro-industrial complex; identify innovations and compare them with domestic and foreign manufacturers; assess the development trends of the agro-industrial sectors, in accordance with the regional characteristics; initiate new agricultural projects, business plans, leasing.

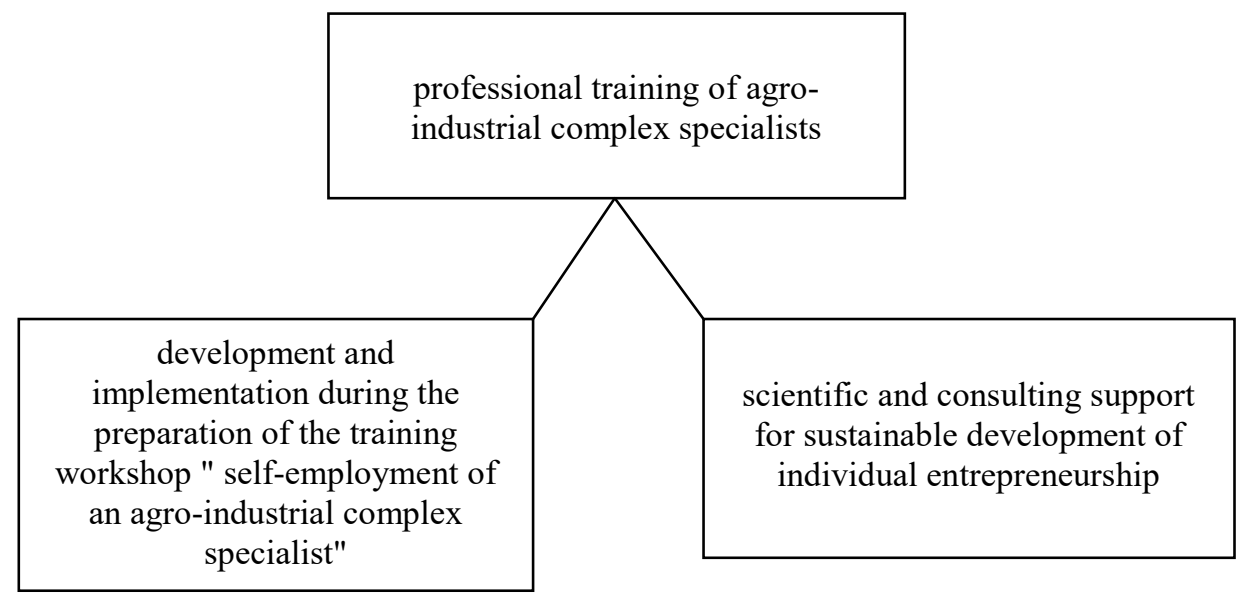

Fig. 1. Target areas of professional training of agro -industrial complex specialists.

The issue of self-employment of specialists in the agro-industrial complex remains relevant today, due to the fact that according to statistical data, employment of graduates of agricultural educational institutions in the agro-industrial sectors, for example, in 2013, amounted to $57-60 \%$. [11]

The purpose of the article and research is to analyze the Russian strategic objectives of the effectiveness of the development of the agro-industrial complex and practical approaches to their implementation in the labor market. The problem of the study is to establish a link between the professional training of specialists of the agro-industrial complex and the presented strategic guidelines for the development of the agricultural industry at the Federal level by various statements. Based on the above, we formulate the hypothesis of the study that the intensity of development of the agricultural industry in the Russian Federation contributes to the effectiveness of professional training of specialists in the agro-industrial complex. 


\section{Materials and Methods}

The empirical array are the texts of passports normative documents of Federal level: the food security Doctrine of the Russian Federation approved by the decree of the President of the Russian Federation of January 21, 2020 N 20; Strategy of development of mechanical engineering for the food processing industry of the Russian Federation for the period till 2030, approved by decree of the Government of the Russian Federation of 30 August 2019 N 1931-R; Order of the Ministry of Finance of Russia from 30.09.2016 N 169H (ed. from 20.04.2018) "about approval of Administrative regulations of providing by Federal tax service of the state service on state registration of legal entities, physical persons as individual entrepreneurs and country (farm) farms" (Registered in the Ministry of justice of the Russian Federation 05.12.2016 N 44557) (with izm. and extra, Intro. effective from 01.10.2018); the Strategy for sustainable development of rural areas of the Russian Federation for the period up to 2030, approved by the order of the Government of the Russian Federation dated February 2, 2015, No. 151-R (ed. order of the Government of the Russian Federation of 13.01.2017 N 8-p); Order of the Ministry of education and science of the Russian Federation of March 30, 2015 n 295 "on approval of the Federal state educational standard of higher education in the field of training 19.04.05 high-tech food production for functional and specialized purposes (master's level)"; Order of the Ministry of education and science of the Russian Federation of March 29, 2010. N 232 " about the approval and introduction of the Federal state educational standard of higher professional education in the direction of training 260500 high-tech productions of food products of functional and specialized purpose (qualification (degree) "master")"; Letter of the Ministry of Finance of the Russian Federation of October 8, 2019 N 03-12-13/77116.

Research methods: cluster analysis, content analysis, generalization, comparative analysis, interpretation.

\section{Results}

At the first stage of the study, we were tasked with determining the goals of official documents and a system of measures for implementing the development of the agroindustrial complex in the Russian Federation. In our opinion, important aspects of the development of the agricultural system, according to the wording presented in the food security Doctrine of the Russian Federation, approved by the decree of the President of the Russian Federation of January 21, 2020. N 20, are: creation of a high-performance sector in agriculture, developing on the basis of modern technologies and provided with scientists and highly qualified specialists; training of specialists in educational programs of secondary professional and higher education for agriculture, fisheries, as well as food and processing industries. [3] Strategy of development of mechanical engineering for the food processing industry of the Russian Federation for the period till 2030, approved by decree of the Government of the Russian Federation of 30 August 2019 N 1931-d examines the issue of support in this sector in the framework of the national project "Small and medium entrepreneurship and support of individual business initiative". [10]

The analysis of the passport Of the strategy for sustainable development of rural territories of the Russian Federation for the period up to 2030, approved by the order of the Government of the Russian Federation of February 2, 2015 No. 151-R (as amended by the order of the government of the Russian Federation of 13.01.2017 N 8-R) showed that there is a shortage of personnel support for the agricultural sector. The document refers to the trend of reducing the equipment of the agro-industrial complex by young graduates. [11]

Analyzing the Federal state educational standard of higher professional education in the field of training 260500 high-tech food production for functional and specialized purposes 
(qualification (degree) "master"), approved by the order of the Ministry of education and science of the Russian Federation dated March 29, 2010. N 232 and the Federal state educational standard of higher education in the field of training 19.04.05 high-tech food production for functional and specialized purposes (master's level), approved by the order of the Ministry of education and science of the Russian Federation of March 30, 2015. N 295 we concluded that the presented requirements for the results of the master's program development are not sufficiently related to those types of professional activities that contribute to the realization of self-employment in future specialists.

So, for example, formed from graduates of agriculture, in particular the food industry, such professional competence as readiness to use organizational-legal foundations of business and management (PC-15) [7,8] promotes the development of professional qualities of self-employment, which is one of the most pressing issues of employment of specialists in this field in the Russian Federation, at the present stage of development of the agroindustrial complex. The question today is not only about the adoption of state measures to address the legal status of self-employed specialists, but also about the definition of pedagogical measures for the training of future specialists of the agro-industrial complex for self-employment. The effectiveness of solving the issue contributes to the professional self-development of graduates.

The results of the analysis are shown in figure 2 .

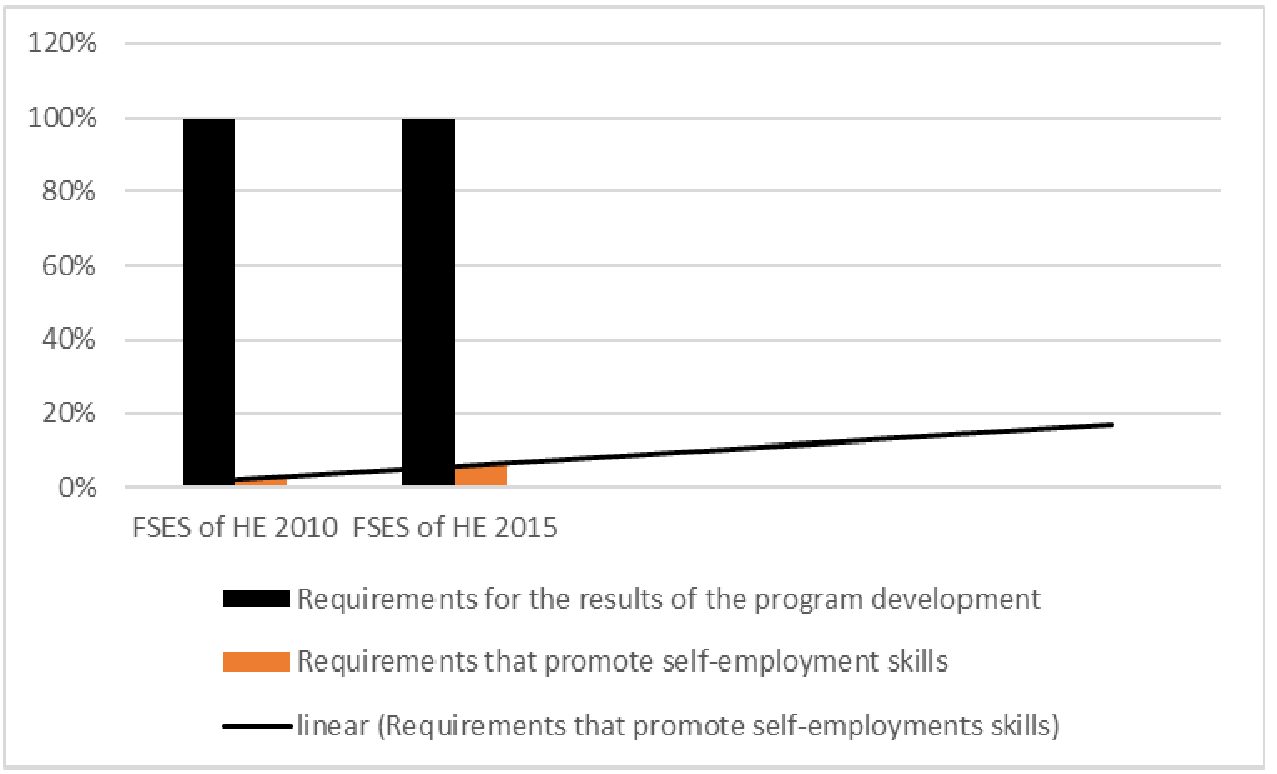

Fig. 2. Share of requirements for the results of mastering the main master's degree programs that contribute to the development of self-employment skills.

According to the presented histogram, it can be seen that from a number of the presented requirements for the results of mastering the main educational programs of the master's degree $[7,8]$, an insufficient number of requirements correlates with the formation of self- employment skills in future specialists.

As studies show, it is the ability of young specialists to organize self-employment will save them from the stressful start of work from the labor exchange. And, obviously, during the training of future specialists in the agricultural sector, an educational program is necessary, the content of which informs students not only about the state of the labor market in the region of residence, but also prepares them for entrepreneurship and selfemployment as one of the strategies for labor activity. Work in this direction can contribute 
to the formation of future specialists in the agro-industrial complex of positive motivation for professions basic knowledge and self-employment skills for entrepreneurial activity, and the result of mastering may be the creation by future specialists of business projects of self-employment (individual entrepreneurship) or the creation of small enterprises.

The second stage of the analytical study was aimed at determining the dynamics of selfemployment of the population in the areas of agro-industrial complex for the production of agricultural products in the period from 2013 to 2019. The results are shown in figure 3 .

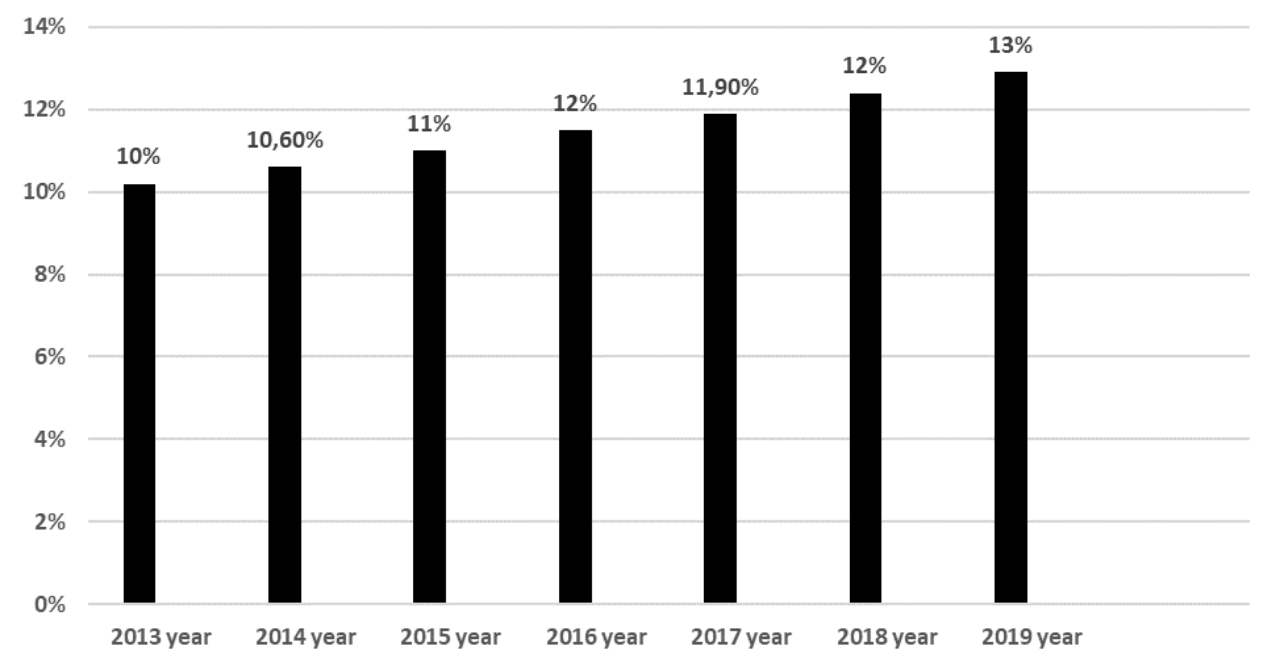

Fig. 3. The share of peasant (farmer) farms and individual entrepreneurs in the production of agricultural products (http://www.consultant.ru/cons/cgi/online.cgi?rnd=44096BAD6BE50FA81A39E1BB064E57F1 $\&$ req $=$ doc\&base $=$ LAW \&n=211112\&dst $=100009 \&$ fld $=134)$.

The presented histogram clearly shows that, since 2013, there has been an increase in farms and individual entrepreneurs in the agricultural industry. There is still a tendency to include the agro-industrial complex in individual business activities. The share of peasant (farmer) farms and individual entrepreneurs in the production of agricultural products should increase in the course of minimizing the shortage of qualified personnel. This position is marked by the decree of the President of the Russian Federation dated January 21,2020 . N20 in the presented risks and threats of food security in the food security Doctrine of the Russian Federation. [3]. But, despite the state support for the development of the domestic agro-industrial complex, unfortunately, the percentage of specialists in the agricultural industry of retirement age is increasing. Staffing is one of the main processes of modernization of the agricultural industry. The introduction of new technological methods of organizing production is impossible without highly qualified specialists.

In connection with the current situation, the decision was made to improve the staffing of the agro-industrial complex. The organization of training of certified specialists should be carried out by balancing the supply and demand in the labor market.

Implementation of training of young specialists in accordance with state guidelines for the development of the agricultural industry, improvement of conditions for obtaining professional education and organization of a system for forecasting the growth of professional requirements for human resources at the Federal and international levels.

It is obvious that the motivational mechanism for both material and moral encouragement of agro-industrial specialists has been improved, thereby increasing the prestige of agricultural industry professions. It is relevant to train personnel potential, 
taking into account the formation of their professional competencies that contribute to the self-determination of a specialist in the labor market and the organization of his selfemployment.

Thus, at the second stage of the study, we came to the conclusion that professional training of specialists in the agro-industrial complex in connection with modern Russian and international market requirements for competitiveness, as well as the requirements for self-employment of the population, is a special form of professional development. The effectiveness of professional development lies in the fact that the acquired theoretical knowledge and practical skills in this area help the specialist determine the trajectory of solving professional and managerial tasks.

\section{Discussion}

Based on the above and the analysis of scientific works of E. V. Bocharova, L. A. Gayazova, N. S. Konotop, G. O. Magomedov, E. I. Margulis, O. S. Melentyeva, O. K. Filatov, and others, we can conclude that professional training of specialists in the agroindustrial complex includes a set of interrelated pedagogical measures necessary for the construction of self-employment of specialists in the agro-industrial complex. Given the specificity of activity of specialists of agrarian industry - a communication with people of different social strata, managerial decision making, organization of interaction of subjects of agro-industrial complex, knowledge of the regulatory framework Federal and international levels, particularly important is the training of competitive personnel.

Thus, the main results of the study allowed us to conclude that the professional preparation for self-employment of future specialists in the agro-industrial complex is the creation of pedagogical conditions that contribute to the development of entrepreneurial business competencies, financial literacy, the formation of leadership abilities, as well as encourage the initiative and creativity. We have determined that the characteristic features of training specialists in the agro-industrial complex for self-employment include: openness, dynamism, plasticity, integrity, concretization, integration, differentiation, targeting, which make a purposeful change in the educational environment of training specialists and improve the parameters of individual educational components.

\section{References}

1. S.I. Belovitskaya, Improving the training of primary school teachers in the field of teaching Russian as a non-native language in the system of additional professional education: thesis (Federal STATE Autonomous educational institution "southern Federal University", 2018)

2. E.V. Bocharova, Historical and social educational thought 9(5), 133-140 (2017)

3. L.A. Gayazova, O.S. Melentyeva, Organization of multi-level cooperation between agricultural higher educational institutions and agricultural enterprises: method. recom. (Rosinformagrotech, Moscow, 2016)

4. The doctrine of food security of the Russian Federation approved by the decree of the President of the Russian Federation of January 21 N 20 (2020)

5. I.A. Kilina, Professional education and youth employment: XXI century. The problem of advanced training for the Russian economy (regional aspect): materials of the international scientific and practical conference, 97-99 (2016) 
6. N.S. Konotop, Enterprise Design. Part 2. Design of confectionery enterprises. Educational and practical guide (Moscow state University named after K. G. Razumovsky, Moscow, 2013)

7. A. Oleinikova, G.O. Magomedov, The Design of confectionary enterprises: Textbook (GIORD, SPb, 2005)

8. Letter from the Ministry of Finance of the Russian Federation dated October 8N 0312-13/77116 (2019)

9. Order of the Ministry of education and science of the Russian Federation of March 29 N 232 (2010)

10. Order of the Ministry of education and science of the Russian Federation of March 30, n 295 (2015)

11. The order of the Ministry of Finance of Russia from 30.09.2016 N 169n (2018)

12. Strategy of development of mechanical engineering for the food and processing industry of the Russian Federation for the period up to 2030, approved by the order of the Government of the Russian Federation of August 30 N 1931-p (2019)

13. Strategy of sustainable development of rural territories of the Russian Federation for the period up to 2030, approved by the order of the Government of the Russian Federation of February 2, 2015 No. 151-R (as amended by the order of the government of the Russian Federation of 13.01.2017 N 8-R)

14. T.V. Uskova, R.Yu. Sulimenko, A.N. Chekalinsky, Agro-industrial complex of the region: condition, tendencies, prospects, monograph (itsed RAS, Vologda, 2013)

15. O.K. Filatov, Modern educational technologies in higher education: theoretical and methodological. research. innovac. PED (MGUTU Publishing house, Moscow, 2004)

16. J. Ghosh, Journal of Agrarian Change 10, 72-86 (2010)

17. K.S. Imai, R. Gaiha, G. Thapa, S.K. Annim, Journal of International Development 25, 1105-1116 (2013)

18. R. Chand, S.S. Raju, L.M. Pandey, Indian Journal of Agricultural Economics 65, 487496 (2010)

19. V. Shalini, K. Prasanna, Energy Economics 53, 40-57 (2016)

20. B. Herrmann, A.S. Kritikos, IZA Journal of European Labor Studies 2, 14 (2013)

21. L.H. Liow, H.J. Skaug, T. Ergon, T. Schweder, Paleobiology 36, 224-252 (2010)

22. D.A. Ruban, Geoscience Frontiers 4, 87-93 (2013)

23. S. Yuan, S. Peng, Renewable and Sustainable Energy Reviews 70, 836-844 (2017)

24. L.W. Bell, A.D. Moore, J.A. Kirkegaard, European Journal of Agronomy 57, 10-20 (2014) 